\title{
Creative and innovative products material floor from shellfish (anadara grandis) waste
}

\author{
Ishak Kadir ${ }^{1, *}$, Arman Faslih ${ }^{1}$, Muhammad Zakaria Umar $^{1}$ \\ ${ }^{1}$ D3 Architecture Study Program, Vocational Education Program, Halu Oleo University, 93232 Southeast Sulawesi, Indonesia
}

\begin{abstract}
The potential wealth of marine resources such as marine fisheries resources is owned by Indonesia. The wealth of marine resources has not been utilized and managed optimally. Today, there are many businesses driven in various fields. The business of building floor crafts from sea shells (anadara grandis) can be pioneered into one form of business. Buton Regency is an archipelago, more than $80 \%$ of its territory consists of sea. During this time, shellfish cultivated by fishermen only used the meat, while the shell removed and became waste. This research aims to utilize shell waste into floor material. The method used in this research was exploration method. The data began with the selection of materials, work tools, and stages of manufacture. Information from various sources is captured and interpreted into a creative idea. The process of analysis was done qualitatively, so it was obtained and raised the shape of the floor. This study concludes that the use of waste shellfish shells into composite floor material is done in three stages. In the first stage, prepared work tools such as glass molds, measuring cups, stirring spoons, brushes, flooring boards, measuring tools, hammers, cutter knives, sandpaper and plastic. The second stage is prepared work materials such as shells, hardener, resin oil, and mirror glass. The third stage is made of floor like shell stage filled with resin oil; The printed floor stage is like smearing a glass mirror on the mold, the resin oil is mixed with hardener, the composite mixture is poured into the mold, the shells are placed in the mold, the shells are poured again with resin oil, and hardener; Stage of removing from glass mold and; finally the floor is given the ballast.
\end{abstract}

\section{Introduction}

Indonesia is called the largest archipelagic country and maritime nation in the world. Waters area is the largest part of the total area of Indonesia. Indonesia has a wealth of potential marine resources such as marine fisheries resources, marine cultivation, marine agriculture resources, and mangrove timber. Wealth of marine resources has not been utilized and managed optimally [1]. Currently, many businesses are driven in various fields, ranging from home industry, medium, to macro business. Types of goods used for business also vary, ranging from food, clothing, and household goods at low prices up to hundreds of millions of rupiah [2].

Sea shells (anadara grandis) are found in Indonesian waters. These shellfish are consumed by the community because they contain lots of protein. During this time, shells tend to be less utilized optimally. Clamshell wastes can be utilized as creative and innovative products such as eco-cement, floors, walls, ornaments, accessories, and starch materials. Portland cement is the largest structural component material required in the construction field. Currently, portland cement used as a sustainable material is an important goal. Alternative raw materials that can be used as replacement of waste-based and environmentally-friendly limestone are shell waste. Ash shells used in the cement making process have the potential as a lime replacement called eco-cement. Ecocement can be used on light construction work [3]. Waste shells that are used as aesthetic elements of the building is one way to raise the locality of the marine archipelago. Shellfish can be utilized in building elements especially floor and wall. The material forming of new materials is influenced by the diversity of shapes and texture colors. Aesthetic flooring material from shell is adapted to the shell shape, motif, and texture of the shells.

Ornaments and accessories made as a business opportunity have a market share. It is based that many people are enthusiastic when buying decoration items and accessories. Ornaments and accessories can be made more unique and look beautiful when created creatively and innovatively [2]. Regarding the CCRF (Code of Conduct for Responsible Fisheries) provisions, the fishery business should be optimized and environmentally friendly. The large amount of solid waste shell shells produced requires serious efforts to be addressed. Calcium content in shellfish can be used in cookies. Shellfish flour shell flour with $2 \mathrm{~N} \mathrm{HCl}$ produces the highest levels of calcium. Shellfish shell flour used in cookies products add nutrient content [4]. Thus it can be concluded that shellfish waste can be utilized as a creative and innovative product thus increasing the income.

\footnotetext{
* Corresponding author: muzakum.uho@gmail.com
} 
Composite is a combination of matrix material that is bonded and reinforced with filler material. The matrix is formed by a composite and bonded with a filler. In general, the composite material used is a thermoset resin adhesive. According to data from the Recycling Workshop in 1993 that waste plastic discharged in large cities reached 4,755 tons per day where $7 \%$ were plastic. When this plastic bag waste is dumped into the environment will pollute the environment. One of the materials formed by wood composites is sawdust. Composites made from flexible plastic waste and sawdust can be applied to floor coverings [5]. Methods that have been developed on the building's floor system are intended for accelerated implementation process and the use of wood is reduced through precast concrete. Steel-concrete and wooden composite floor plate systems are widely used, because of the following; 1) in the execution process only required scaffolding with a distance of about $1 \mathrm{~m}$; 2) precast plate in the form of curve tile functioned as formwork; 3) fused with concrete; 4) preprinted components are assembled, molded whole beams, support beam combined with floor plate, and casted in place [6]. One effort to optimize the utilization of wood is done by using the remaining sawn timber for the production of composite floor boards. The making of floor boards from the rest of the processed wood is more efficient than the making of floor boards that use the rest of the wood. The remaining processed wood for optimal floorboard products is utilized as surface coating material and for panel products [7]. One of the alternative floors used in multi-storey buildings is composite floor plates of reinforced concrete. This wood component is functioned as a beam divider and as a floor plate. This precise technology is expected to be a complement to modular home buildings. The developed composite floor system produces the trend of beam capacity curve to be a ductile. The wood-reinforced concrete composite system can be an alternative to the floor structure system [8]. Thus it can be concluded that the building floor can be made of composite with different filler material.

The business of building floor crafts from sea shells (anadara grandis) can be pioneered into one form of business. Buton Regency is an archipelago, more than $80 \%$ of its total area or $\pm 21,054 \mathrm{~km}^{2}$ consists of sea. Potential fisheries and marine is quite high owned by this region, such as coral reef ecosystems, seagrass ecosystems, mangrove forests, and high seas. Cultivated Mollusca commodities such as pearl shells, japing shells, fur shells, green shells, abalone, lola, axes, and giant kimah. The coral and sand substrate biota are inhabited by lola and abalone in Lasalimu, South Lasalimu, Batu Atas, Sampolawa, Siompu, Lakudo, Wabula, and Mawasangka. During this time, shellfish cultivated fishermen only used meat, while the shell is removed and become waste. Thus, this phenomenon is captured and processed creatively and innovatively as a floor material. This research is aimed to utilize shell waste into floor material.

\section{Methodology}

The method used in this research is exploration method. Data begins with the selection of materials, work tools, and stages of manufacture. Information from various sources is captured and interpreted into a creative idea. The basic concept is done and developed pragmatically on the shape of the floor. The process of analysis is done qualitatively, so it is obtained and raised the shape of the floor. The ground floor shape obtained is transformed from the parameters to the resulting flooring of clamshells and can be applied to the building.

\section{Result and Discussion}

\subsection{Work tools}

The work tools used to make flooring material from shellfish (anadara grandis) are, as follows: 1) Glass molds made of clear glass type with $5 \mathrm{~mm}$ thick. The glass mold is made as follows: The first glass mold is made base mold with the size $250 \mathrm{~mm}$ x $250 \mathrm{~m}$. A second mold is made of a frame placed on top of the base mold. The frame is made according to the size of the base print. The thickness of the molded frame made is $10 \mathrm{~mm}$, because the frame of the mold is arranged into two layers. The inner mold thickness is $10 \mathrm{~mm}$. The frame mold placed on the base mold is adhesive by using a mixture of resin and hardener by dripping on the edge of the base mold.

All of the frame frames at the angular assembly are patched with plastisin to keep the wet composite material out of the mold. Thus, mold of floor material from shells is formed; 2) Measuring cup used glasses of mineral water with dosage $240 \mathrm{ml}$; 3) The stirrer spoon is used to stir the mixture of resin and hardener oil to mix evenly; 4) The brush is used to smear the glass mirror on the glass mold so that the floor material is not sticky when lifted from the mold; 5) The boards used are plywood boards or gypsum that have been unused. This tool is used as an idler during the printing stage to allow the floor volume to be flat and symmetrical; 6) The measuring instrument used is meter and ruler; 7) Stationeries are used during the manufacture of prints such as markers; 8) The hammer is used to break shells that are not fit in the mold and to destroy the shells. The crushed shells are used as floor fillers; 9) The cutter knife is used to cut out the edge of the mold that appears; 10) The abrasive tool is used to smooth the sides of the printed floor for aesthetics; 11) Plastisin is used to cover the gap at the assembly of the frame so that the liquid in the mold does not come out of the mold.

\subsection{Work materials}

The working materials used to make the floor material from the shells (anadara grandis) are (shown in Figure 1), as follows: 1) seed shells used are taken from Pasarwajo Sub-district, Buton Regency. The characteristics of shellfish from this area of the most prominent are clean white as sand. So good when used as a material filler floor of shellfish. Shellfish prior to use as a floor material should be washed with clean 
water and laundry. Whole shellfish is used as the main object of floor material. Shellfish are crushed as filler elements and placed between the complete shells, so that the filler material in the mold becomes solid. The size of the shells used as floor fillers varies, so the shell material placed in the mold appears. The maximum size of whole shells inserted as filler material is $15 \mathrm{~mm}$. The size of the shellfish exceeding that size is destroyed as a floor filler; 2) Hardener is used as an accelerating material to harden the composite material. The price of one bottle of hardener sold in the market is Rp 7000 (Seven thousand rupiah) per bottle. The hardener composition used for resin oil to create a floor with a size of $200 \mathrm{~mm}$ x $200 \mathrm{ml}$ is $4 \mathrm{ml}$; 3) The resin oil used per $240 \mathrm{ml}$ dose of the hardener is $2 \mathrm{ml}$ (99\%: $1 \%$ ). Price of $1 \mathrm{~kg}$ resin oil valued Rp 4000 (Forty thousand rupiah). One piece of floor material with a size of $200 \mathrm{~mm} \times 200 \mathrm{~mm}$ is used $480 \mathrm{ml}$ of resin oil. Resin oil functioned as the main raw material for forming flooring; 4) Mirror glass functioned as a polishing material before the mold is filled so that the floor easily separated from the mold. Mirror glass one tin valued $\mathrm{Rp} 150000$ (One hundred fifty thousand rupiah).

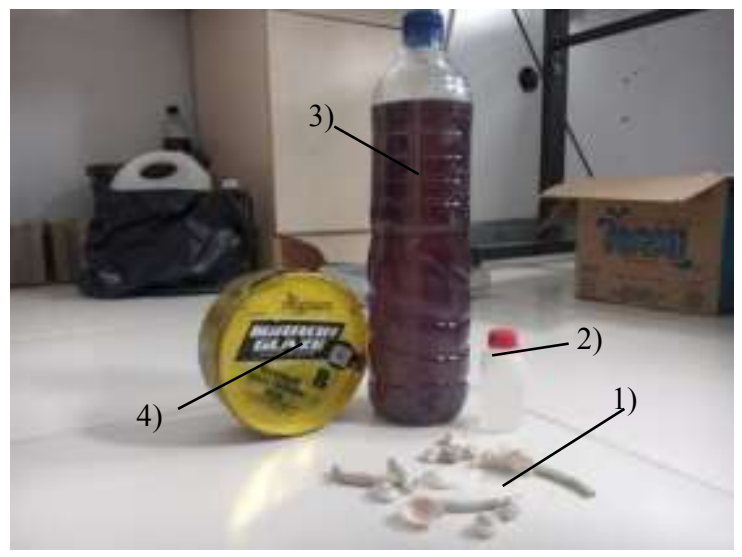

Fig. 1. Working materials used to make flooring material from shellfish.

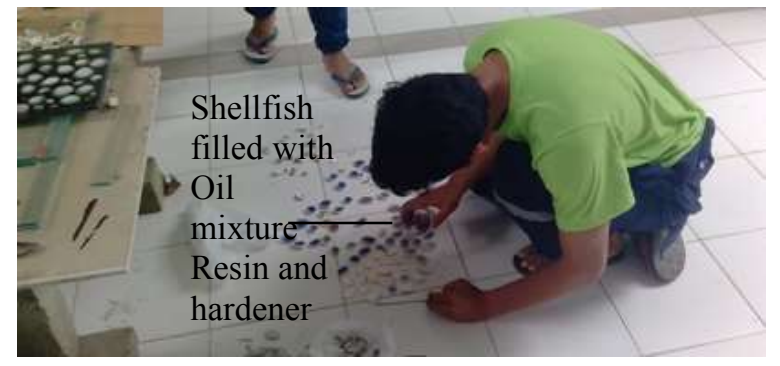

Fig. 2. Fan shaped shells filled with a mixture of resin and hardener oils.

\subsection{Making floor}

\subsubsection{Mixing}

Fan shaped shells are filled one by one using resin and hardener oils with the content composition used $99 \%$ : $1 \%$. The filling of the composite mixture against these shellfish is intended to make solid shell so that the floor is sturdy. The shells filled with quick dry oil resin for about 5 minutes. This stage of the preparation is done with great care that the mixture of resin and hardener oil is not spilled (Fig. 2).

\subsubsection{Printing}

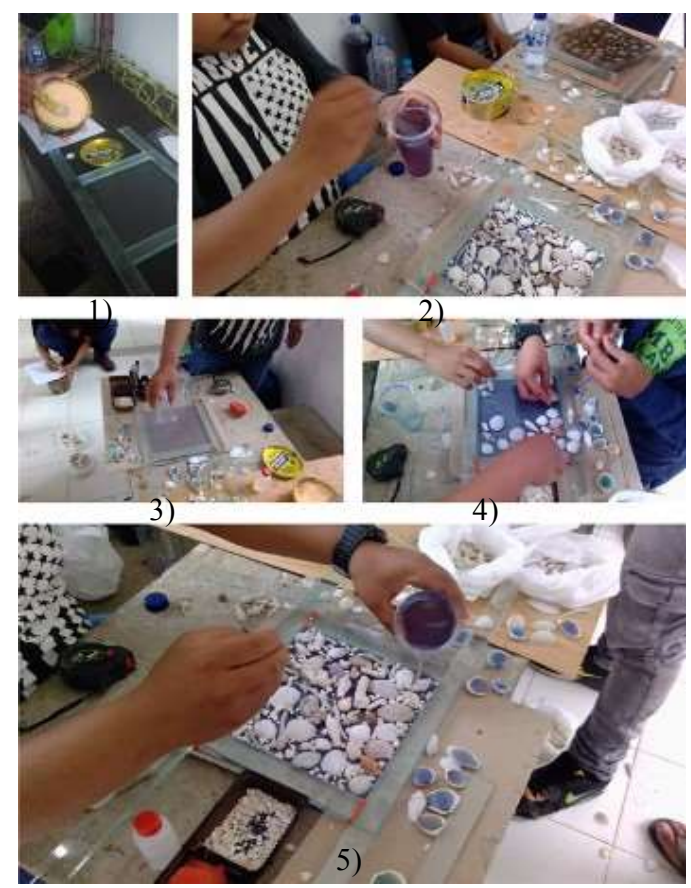

Fig. 3. Stages of printed floor

The stages of the floor are printed (Fig. 3), as follows: 1) Mirror glass is smeared with brush on a glass mold. Mirror glass smeared across the glass surface including the thick edges of the glass. The more glass mirrors smeared in the mold the easier it is to release the floor; 2) Oil resin and hardener mixed with 99\%: $1 \%$ composition. The mixture is stirred with a spoon to keep it flat; 3) The composite mixture is poured into a mold with a thickness of 3-4 mm and is waited until it is rather dense. Solid composites are known by piercing with stick; 4) Mixture of composite that began solid put shells. The shells are placed one by one and close together. The shapes and types of shells used as floor fillers vary. The gaps between the shells are filled with shellfish crushed in order to be aesthetically pleasing. The shell stage placed in the mold needs to be done quickly, because to anticipate a quick solid resin mixture; 5) After all the shells have been installed immediately pour the resin oil mixture over the entire shell surface. Poured resin oil needs to get out of mold. At this stage it should be carefully observed so that the mold is not tilted. Sloping mold is feared uneven floor thickness. At this stage also need to be observed because of frequent bubble phenomena. The empty air inside the mixture is called a bubble phenomenon. This happens because the heat from the composite mixture presses the air from the shells. This phenomenon is anticipated by removing the air by stabbing it with a stick. After the floor is printed and waited until solid for 10 minutes. 
Floors that have been dry and dense can be known by the way when touched hot.

\subsubsection{Release}

After the floor is hot touched immediately remove the mold frame with great care so as not to damage the floor (Fig. 4). Frames should be opened on both sides in advance. After the floor is not too hot, the next frame is released.

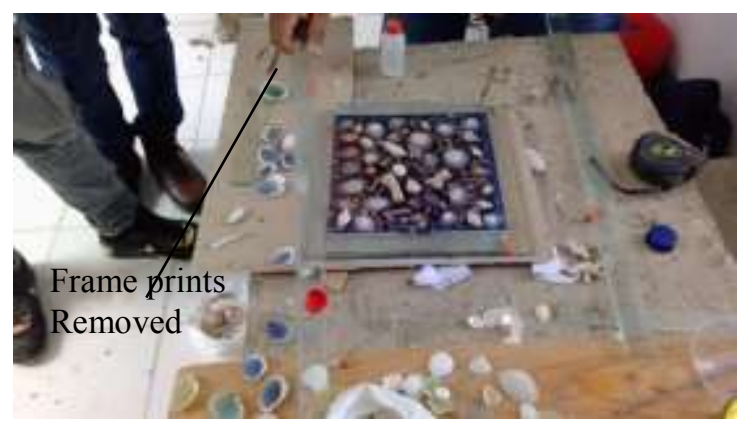

Fig. 4. Frame mold removed from solid floor.

\subsubsection{Ballast}
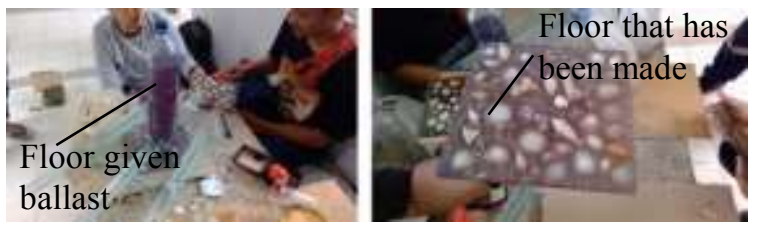

Fig. 5. The floors are weighted in the corners and floors that have been created.

The removable floor material has the potential of curved corners due to the heat released from the composite mixture. This is anticipated by weighing the corners of the floor. Loads that are fed on the floor corners for 1520 minutes or until the floor is not hot. After that, the floor is released from the ballast above it. Thus, the floor material formed from the shell is flat and the corners are not curved. The size of the floor material made is 200 $\mathrm{mm} \times 200 \mathrm{~mm} \times 5 \mathrm{~mm}$. The amount of floor material made is one piece (Fig. 5).

\section{Conclusion}

This study concludes that the use of waste shellfish shells into composite floor material is done in three stages. In the first stage, prepared work tools such as glass molds, measuring cups, stirring spoons, brushes, flooring boards, measuring tools, hammers, cutter knives, sandpaper and plastic. The second stage is prepared work materials such as shells, hardener, resin oil, and mirror glass. The third stage is made of floor like shell stage filled with resin oil; The printed floor stage is like smearing a glass mirror on the mold, the resin oil is mixed with hardener, the composite mixture is poured into the mold, the shells are placed in the mold, the shells are poured again with resin oil, and hardener;
Stage of removing from glass mold and; finally the floor is given the ballast.

\section{References}

1. R. Adisasmita, 2010, Pembangunan Ekonomi Maritim (Hasanuddin University: Makassar, 2010)

2. E.D.T. Sari, A.D. Rismana, Suseno, C.A. Tyas, U. Lailassalami, Pemanfaatan Kerang Laut Untuk Usaha Souvenir Buatan Tangan, in Program Kreatifitas Mahasiswa, Fakultas Ilmu Komputer, Dian Nuswantoro University, Semarang, 1-2 (2013)

3. N.A. Syafpoetri, M. Olivia, L. Darmayanti, Pemanfaatan Abu Kulit Kerang (anadara grandis) Untuk Pembuatan Ekosemen, Thesis Undergraduate, Department of Civil, Faculty of Engeneering, Riau University, Pekanbaru, 1-2, 14 (2013)

4. T.W. Agustini, A.S. Fahmi, I. Widowati, A. Sarwono, Utilization of Asian Moon Scallop (amusium pleuronectes) Shell Waste on Making of Calcium-Rich Cookies, J. Pengolahan Hasil Perikanan Indonesia XIV, 8-9, 13 (2011)

5. D.W. Nurhajati, A. Yuniari, Herminiwati, A Composit From Flextable Plastic Waste and Saw Dust, J. Majalah Kulit, Karet, dan Plastik 19, 07, 12 (2003)

6. A. Triwiyono, P. Siringoringo, A. Ndaru, Z. Ohlin, P. Ilham, A. Tatyana, Sistem Lantai Komposit dari Bahan Pracetak Support Beam, Curve Tile, dan Beton Cor di Tempat, in Prosiding Seminar HAKI Jakarta, 1, 8 (2010)

7. Fakhri, H. Gussyafri, Syafruddin, Pemanfaatan Sisa Potongan Kayu Olahan Untuk Produk Papan Lantai Komposit, J. Aptek 3, 79, 83 (2010)

8. Y.A. Pranata, A. Kristianto, Pengembangan Sistem Lantai Komposit Berbasis Material Lokal Untuk Bangunan Kayu Bertingkat, In Seminar Nasional Pengabdian kepada Masyarakat, Thesis Undergraduate, Department of Civil, Faculty of Engeneering, Kristen Maranatha University, 424, 430 (2016) 